\title{
LEAF LITTER IN TWO SOUTHERN TASMANIAN CREEKS AND ITS RELEVANCE TO PALAEOBOTANY
}

\author{
by R. J. Carpenter and P. Hørwitz \\ (with one table and one text-figure)
}

\begin{abstract}
CARPENTER, R. J. \& HORWITZ, P., 1988 (31:x): Leaf litter in two southern Tasmanian creeks and its relevance to palacobotany. Pap. Proc. R. Soc. Tasm. 122(2): 39-45. https://doi.org/10.26749/rstpp.122.2.39

ISSN 0080-4703. Botany Department (R.J.C.) and Centre for Environmental Studies (P.H.), University of Tasmania, G.P.O. Box 252C, Hobart, Australia 7001.
\end{abstract}

Benthic and drifting leaf litter were examined in two parallel creeks in mixed forest in southern Tasmania, and the occurrence of whole leaves recorded. Nothofagus cunninghamii leaves were dominant in both the benthic and drift samples, Atherosperma moschatum occurred in the drift but only in trace quantities in the benthic samples, Phyllocladus aspleniifolius occurred in the benthos but only in trace quantities in the drift samples, and whole Eucalyptus obliqua leaves were absent from all samples. Otherwise most species occurred in similar proportions in both creeks and for both sampling strategies. It is concluded that the processes of litter input, leaf buoyancy, and leaf breakdown will result in an unequal potential for fossilisation of the leaves of different species; accordingly, attempts to reconstruct vegetation using macrofossils need to be approached with caution.

Key Words: leaf litter, mixed forest, creek benthos, drift, southern Tasmania, palaeobotany.

\section{INTRODUCTION}

Variations in the relative proportions of the leaves of different species represented as leaf litter at surface and benthic levels in lotic and lentic systems, when compared to the surrounding vegetation, may have important implications for both palaeobotanical and limnological research.

Leaves may reach a freshwater system by falling in directly from overhanging vegetation, being blown in (usually from nearby canopy trees) or washed from the litter of the forest floor. The number of whole leaves reaching the water will be dependent upon the amount of litter produced by each species, their size, shape and density, and their susceptibility to mechanical and biological breakdown. Furthermore, buoyancy of the leaves of different species varies so that some may be carried relatively long distances by wind and current whereas others, such as Eucalyptus coccifera, fall directly and sink rapidly (Hill \& Gibson 1986a). Leaf breakdown may commence with the leaching of water soluble substances followed by invasion of the leaf by micro-organisms, which in turn may be grazed by invertebrates. It is therefore likely that the macrofossil record will be biased towards plants with resistant leaves growing along watercourses. Many of these factors have been discussed by Ferguson (1985) and Birks \& Birks (1980).

Little information regarding the input of potential macrofossils into southern hemisphere freshwater systems exists, while even less is known of the feeding ecology of rainforest stream invertebrates (Bunn 1986), and how this may effect the longevity of leaves in the system. The study by Hills \& Gibson (1986a) of the distribution of potential macrofossils in Lake Dobson, Tasmania related particularly to subalpine woodland dominated by Nothofagus cunninghamii and Epacridaceae/Proteaceae sclerophyll vegetation and not to common Tasmanian cool temperate rainforest elements such as Atherosperma moschatum (sassafras), Eucryphia lucida (leatherwood) and Phyllocladus aspleniifolius (celery-top pine).

Nothofagus leaves with affinity to $N$. cunninghamii and $N$. moorei are abundant in Tasmanian Tertiary deposits (Hill 1983, Hill 1984, Hill \& Macphail 1983, Hill \& Gibson 1986b) and Phyllocladus cladodes have been found in several deposits (Hill \& Macphail 1983, 1985). However, other rainforest taxa such as Atherosperma (Monimiaceae), Eucryphia (Eucryphiaceae), Anopterus (Escalloniaceae) and Aristotelia (Elaeocarpaceae) have a meagre Tertiary 


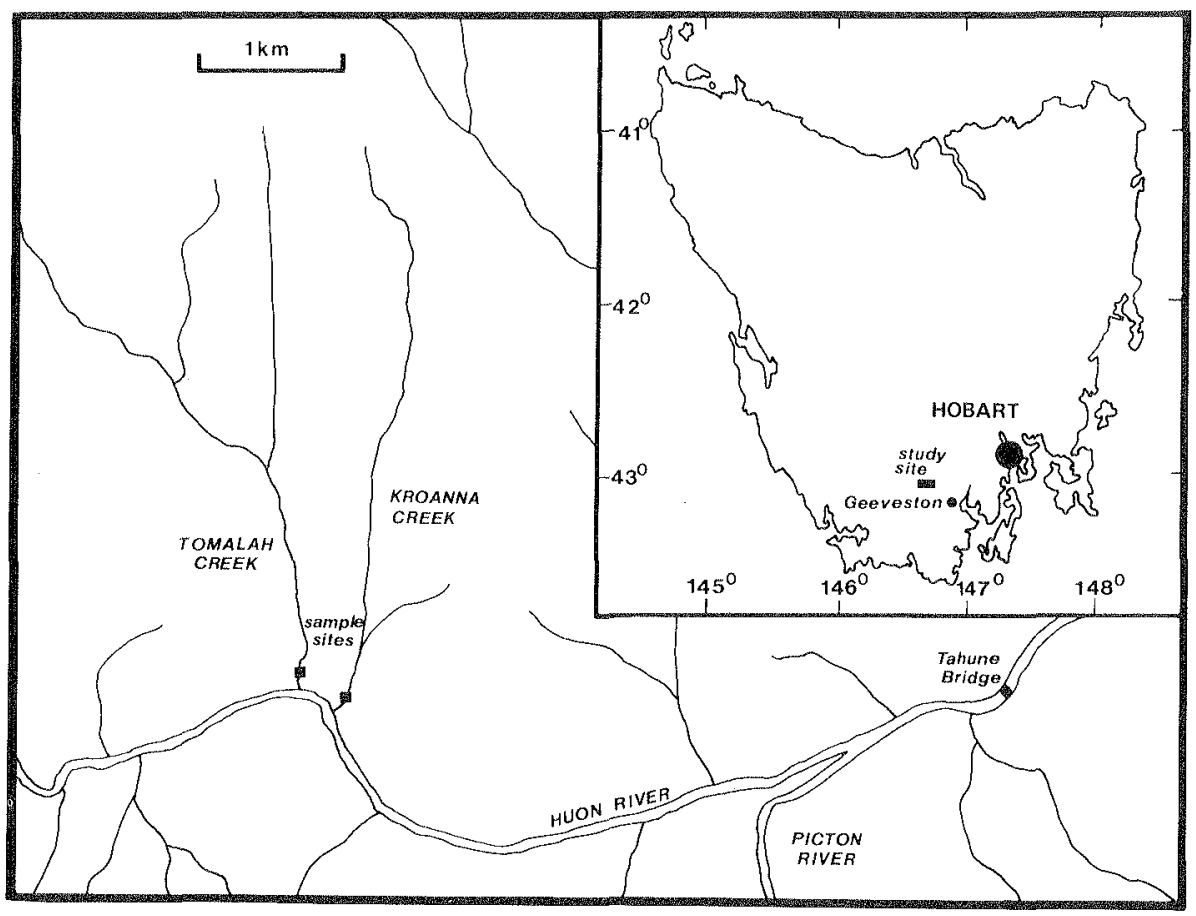

FIG. I - The locations of the study sites. For details see Huon 1:100 000 Sheet 8211 (second edition).

macrofossil record despite being considered to have undoubted Gondwanic ancestry (e.g. Raven \& Axelrod 1972, Barlow 1981, Jarman \& Brown 1983). Tertiary leaves of Eucryphia and Atherosperma have been documented only from the Regatta Point Plio-Pleistocene deposit (Hill \& Macphail 1985). Furthermore, taxa typical of Tasmanian mixed and wet forest such as Eucalyptus, Olearia, Phebalium and Pomaderris have no confirmed Tasmanian Tertiary macrofossil record despite being common components of the extant vegetation. A single fossil Acacia phyllode is known only from Regatta Point, but is distinct from extant Tasmanian species (Hill \& Macphail 1985).

The aim of the present study was to identify the proportionate species composition of whole leaf litter in southern Tasmanian streams which flow through mixed forest, and to determine whether these proportions are altered by using different methods of in situ collection. In doing so, we hoped to gain some insights into the potential of leaves of the above taxa to become fossilised, and to relate this information to their relative representation in the Tasmanian fossil record.

\section{METHODS AND MATERIALS}

Two permanent streams were selected; Tomalah Creek and Kroanna Creek. Each flows into the Huon River ( at approximately $80 \mathrm{~m}$ a.s.l.) $4-5 \mathrm{~km}$ upstream from Tahune Bridge, near Geeveston, southern Tasmania (fig. 1). Sampling was conducted at sites approximately $30 \mathrm{~m}$ upstream of the confluence between each stream and the Huon River. As the streams flow closely parallel to each other, the two sampling sites were no more than $400 \mathrm{~m}$ apart. The present study was undertaken during an investigation of drifting invertebrate fauna and the effects of logging activity on this fauna (conducted by the Tasmanian Inland Fisheries Commission).

The streams flow over Permian marine mudstone and the bed loads of the streams consist predominantly of rocks between 0.03 and $0.15 \mathrm{~m}$ in diameter.

Kroanna Creek is approximately $0.5-1 \mathrm{~m}$ wide at basal flows and at the same levels Tomalah Creek is approximately $1-2 \mathrm{~m}$ in width. Whereas the hydrologies of the two streams are essentially similar with respect to temperature regimes, $\mathrm{pH}$, 
turbidity and conductivity (R. King, pers. comm. 1987), Kroanna Creek carries approximately half the water of Tomalah Creek.

The composition and abundance of plant species in the surrounding vegetation between the creeks was observed and is best described as mixed forest with eucalypts being the major canopy trees. Wet sclerophyll species such as Eucalyptus obliqua, Pomaderris apetala, and Phebalium squameum dominate the better drained sites with an understorey of plants including Coprosma quadrifida, Cyathodes glauca, and Polystichum proliferum. Rainforest species such as Nothofagus cunninghamii, Eucryphia lucida, Anopterus glandulosus and Atherosperma moschatum become more prevalent in the creek gullies. Three Acacia species were recorded. Dicksonia antarctica was common along both streams.

Two sampling techniques were used in this study; one to examine the benthos and one to examine drift. At each site ten benthic samples were taken using a modified Surber sampler (see Winterbourn 1985); such nets are one of a number of standard techniques for sampling the benthic invertebrates of freshwater systems. For each sample an area of $0.1 \mathrm{~m}^{2}$ was enclosed and the substratum was manually disturbed to a depth of $50-100 \mathrm{~mm}$. This disturbance throws material such as benthic invertebrates, plant matter (coarse particulate organic matter - CPOM), and substrate into the water column to be carried into the net of $500 \mu \mathrm{m}$ mesh.

The drift of each creek was sampled by using a drift net, of mesh $500 \mu \mathrm{m}$, which enclosed an area of $0.1 \mathrm{~m}^{2}$. The nets were fixed into place perpendicular to the water flow in riffle sections of the creek and material drifting downstream over a 24-hour period was collected. The nets sampled the entire depth of the creeks. On the 8 and 9 October 1986 four 24-hour drift samples were collected from Tomalah Creek and two 24-hour drift samples from Kroanna Creek. No significant rainfalls had occurred immediately prior to the sampling period (thus sampling was not connected during a spate).

All samples were preserved immediately in $5-10 \%$ formaldehyde solution and later stored in $70 \%$ alcohol to await sorting. Each sample was then passed through a $2 \mathrm{~mm}$ sieve to retain CPOM. Whole leaves, defined as possesing both base and apex, were identified to species level and tallied. The presence of identifiable leaf fragments was recorded as supplementary information. Only whole leaf data were quantified since we consider that whole leaves would be more likely to be identified in palaeobotanical studies. It is therefore to be expected that some bias towards smaller leaves will occur since large leaves will be more susceptible to mechanical fragmentation in the creeks.

\section{RESULTS}

All samples were sorted individually (as above) but combined to give both the number and proportion (expressed as a percentage) of each species found in either the benthos or the drift of each creek (table 1). The combination of samples allowed for easier comparisons and analyses and was made possible by the high degree of replicability between each related sample.

With few exceptions (see discussion) the species representation in the litter of the creeks was a good reflection of the nearby vegetation along the creeks.

In general the results from the two creeks were similar. In the benthic samples Nothofagus cunninghamii was by far the most commonly occurring species, with an average abundance of $73 \%$ in Tomalah Creek and $80 \%$ in Kroanna Creek. The major difference between the two creeks was the amount of Acacia verticillata; in Kroanna Creek it was the second most common species with $10 \%$, whilst in Tomalah Creek it was found in only trace quantities and Eucryphia lucida was subdominant with 19\%. Phyllocladus aspleniifolius and Acacia melanoxylon were present in minor proportions in both creeks. The remaining species occurred only in trace quantities.

In the drift samples $N$. cunninghamii was also the dominant species with $60 \%$ in Tomalah Creek and $51 \%$ in Kroanna Creek. Similar to the results for benthic samples, drifting whole leaves of Acacia verticillata were abundant $(33 \%)$ in Kroanna Creek but were absent from Tomalah Creek. Trees of this species overhang Kroanna Creek and produce abundant small phyllodes. In Tomalah Creek Atherosperma moschatum and Eucryphia lucida were present in high proportions in the drift whilst the small leaves of Coprosma quadrifida and Leptospermum lanigerum were present in low numbers and the six other species were found in only trace quantities. In Kroanna Creek Atherosperma moschatum, Eucryphia lucida, Acacia melanoxylon, Phebalium squameum and Coprosma quadrifida were present in low numbers and four other species occurred in trace proportions. Frond fragments of the tree fern Dicksonia antarctica were common and identified 
TABLE 1 Composition of Leaf Litter: the Number* and Percentage for Each Species
in Each of the Two Creeks

\begin{tabular}{|c|c|c|c|c|}
\hline \multirow[t]{2}{*}{ Species } & \multicolumn{2}{|c|}{ Benthos } & \multicolumn{2}{|c|}{ Drift } \\
\hline & Tomalah & Kroanna & Tomalah & Kroanna \\
\hline Nothofagus cunninghamii & $673(73)$ & $390(80)$ & $358(60)$ & $99(51)$ \\
\hline Eucryphia lucida & $174(19)$ & $17(4)$ & $83(14)$ & $9(5)$ \\
\hline Acacia verticillata & 1 (trace) & $49(10)$ & - & $64(32)$ \\
\hline Atherosperma moschatum & 5 (trace) & 4 (trace) & $133(22)$ & $7(4)$ \\
\hline Acacia melanoxylon & $43(5)$ & $12(2)$ & 1 (trace) & $5(3)$ \\
\hline Phyllocladus aspleniifolius & $17(2)$ & $10(2)$ & 1 (trace) & - \\
\hline Pomaderris apetala & 8 (trace) & 1 (trace) & 3 (trace) & 1 (trace) \\
\hline Phebalium squameum & - & 4 (trace) & - & $4(2)$ \\
\hline Coprosma quadrifida & - & - & $10(2)$ & $4(2)$ \\
\hline Aristotelia peduncularis & - & - & 3 (trace) & - \\
\hline Prionotes cerinthoides & 3 (trace) & - & 1 (trace) & - \\
\hline Monotoca glauca & - & - & 1 (trace) & - \\
\hline Leptospermum lanigerum & 2 (trace) & - & $8(1)$ & 1 (trace) \\
\hline Anopterus glandulosus & - & - & - & 1 (trace) \\
\hline Trochocarpa $\mathrm{sp}$ & - & 1 (trace) & - & 1 (trace) \\
\hline Olearia persoonioides & 1 (trace) & - & - & - \\
\hline Totals & 927 & 488 & 602 & 196 \\
\hline
\end{tabular}

* Whole leaves only.

in every sample from both creeks. Acacia dealbata pinnae were common in Tomalah Creek. Species which were only rarely recorded as large foliage fragments were Eucalyptus obliqua, Olearia argophylla, Orites diversifolia, Blechnum nudum and $B$. wattsii. With the exception of $E$. obliqua these species were uncommon in the regional vegetation.

A total of 2213 whole leaves were counted representing 16 species. An additional seven species were found as large leaf, phyllode or frond fragments only (as above), bringing the total to 23 species in the leaf litter of the two streams.

\section{DISCUSSION}

The techniques of benthic and drift sampling, usually reserved for the analysis of freshwater invertebrates, have shown some interesting differences between the behaviour of leaves in lotic systems.

Nothofagus cunninghamii leaves were dominant in all samples whereas leaves of the major canopy tree in the area, Eucalyptus obliqua, were only recorded as rare, incomplete fragments. Nothofagus leaves are small and coriaceous whereas fallen eucalypt leaves are apparently poorly dispersed (Hill \& Gibson 1986a) and seem more susceptible to breakdown. Other researchers have also noted a relatively rapid decomposition of eucalypt leaves. For instance, O'Keefe \& Lake (1987) found that the consumption of eucalypt leaves by invertebrates began almost as soon as they were placed in a study stream in southern Victoria. The difference in abundance between Nothofagus and Eucalyptus leaves may also be due to the fact that $N$. cunninghamii trees were relatively more abundant in the moister, shadier creek gullies whereas the eucalypts were usually found in drier locations. Thus in a mixed forest such as this, it can be expected that rainforest species close to the creek are likely to contribute a larger proportion of leaf litter to the creek than Eucalyptus spp. and other plants of drier habitats. In order to provide some additional data with which to assess this idea, in May 1987 a transect was constructed perpendicular to each creek, and leaf 
litter was collected and tallied from $1 \mathrm{~m}^{2}$ plots at $5 \mathrm{~m}$ intervals up to $25 \mathrm{~m}$. In all over 2500 leaves were tallied. The results were generally as expected. For instance, near Kroanna Creek $N$. cunninghamii leaves decreased from being the most commonly collected neat to the creek until they comprised only $3 \%$ of the total leaf litter at $25 \mathrm{~m}$ from the creek, whereas $E$. obliqua leaves were low in number and proportion (about $1 \%$ ) next to the creek and increased to $11 \%$ at $25 \mathrm{~m}$. Atherosperma moschatum leaves were very common (about $20 \%$ ) close to the creek but were absent at $25 \mathrm{~m}$. Eucryphia lucida and Pomaderris apetala leaves were common along transects; the former especially near the creeks, and the latter in drier areas. (The under-representation of Pomaderris leaves in the creeks seems to be due to fragility as numerous large leaf fragments were recovered, but comparatively few whole leaves.) Leaves of the shrubs Anopterus glandulosus, Cyathodes glauca and Coprosma quadrifida were very rare in the litter collections, and no phylloclades of Phyllocladus aspleniifolius were found.

Two species displayed notable variations in abundance between drift and benthic samples. Atherosperma moschatum leaves were mainly in drift samples whereas Phyllocladus aspleniifolius was more abundant in benthic samples. These differences probably relate to differences in buoyancy and susceptibility to biological and physical breakdown. Sassafras leaves will readily float and are unlikely to reach the benthos intact. This appears to be principally due to leaching and microbiological breakdown and not due to physical destruction since skeletonised leaves were occasionally recovered as well as leaves in which the mesophyll and epidermis were separating. Broken fragments were rarely recovered. Howard (1973) also noted the rapid breakdown of sassafras leaves relative to those of Nothofagus cunninghamii.

The longer leaves remain afloat the less chance they will have of settling out undamaged in anaerobic situations where they could become fossilised. The phylloclades of Phyllocladus aspleniifolius are comparatively very thick and leathery and it is quite likely that they would both sink rapidly, and therefore not occur in the drift, and be relatively resistant to mechanical or biological breakdown having reached the benthos. It is probable that the benthic phylloclades have been washed from an unknown distance upstream, since trees were not found close to either creek and no phylloclades were found in the transect litter.

Leaves of other species not recorded as proximal shrubs or trees or in the transect litter were of Aristotelia peduncularis, Prionotes cerinthoides, Monotoca glauca, Leptospermum lanigerum, Olearia persoonioides and Trochocarpa $\mathrm{sp}$. In general these small leaves were found in the drift only and seem to have reached the sampling site from unknown distances upstream.

It is considered that the major results found here, i.e. that Nothofagus cunninghamii leaves are dominant in both benthic and drift samples, Atherosperma moschatum occurs in the drift but only in trace proportions in the benthos samples and vice versa for Phyllocladus aspleniifolius, and that whole Eucalyptus obliqua leaves were absent from all creek samples, are unlikely to be altered significantly by seasonal variation. Turnbull \& Madden (1983) found that the number of basal stems at a site accounted for $64 \%$ of the variance in litterfall in southern Tasmanian forests. The remaining amount of variation is unlikely to cause a significant shift in the proportions of leaves of the above species in creeks. For instance a drift sample from Tomalah Creek taken in January 1987 comprised a large quantity of $N$. cunninghamii leaves $(62 \%$ of all whole leaves found), $8 \%$ Atherosperma moschatum leaves and did not contain E. obliqua leaves (with Eucryphia lucida forming the bulk of the remaining leaves). These are very similar results to those found during the observation period in October 1986.

It must be stressed that we do not imply that the sample site is a model of a past situation, or that necessarily it represents a potential fossil site or means of litter conveyance to a fossil site. However, we suggest that the evidence presented here may at least in part be used to explain certain features of the fossil record, including the absence of some taxa which are abundant in extant forests. It is of interest that the benthic data obtained in this report reflect the macrofossil composition of Tasmanian Quaternary sites and the Regatta Point Plio-Pleistocene deposit (Colhoun 1980, Hill \& Macphail 1985, R.S. Hill, pers. comm. 1987). These deposits tend to be dominated by Nothofagus, with Eucryphia, Phyllocladus and rare Atherosperma and Acacia macrofossils.

The results suggest that the processes of leaf buoyancy and breakdown and differential litter input mean that the leaves of Eucalyptus obliqua and Atherosperma moschatum will fossilise only rarely despite trees of these species being locally common, whereas leaves of Nothofagus cunninghamii and Phyllocladus aspleniifolius will fossilise readily and abundantly, possibly leading to an overestimation of their actual presence in the 
surrounding forest. In this respect Hill \& Gibson (1986a) predicted, on the basis of the proportions and distribution of leaves in Lake Dobson, that in the surrounding forest Eucalyptus coccifera was rare in relation to Nothofagus cunninghamil, whereas in fact the eucalypts are the canopy dominants. No reliable eucalypt macrofossils are known from Tasmania. The paucity of fossil leaves assignable to taxa typical of eucalypt dominated sclerophyll vegetation may also be due to the relatively recent spread of this vegetation type associated with the arrival of humans and frequent fires (Singh, Kershaw \& Clark 1981). Eucryphia is the only true rainforest plant that is well represented in the litter but has virtually no macrofossil record from the Tertiary. There is therefore some evidence that leatherwood is unlikely to have been common in the Tertiary, at least close to water, a habitat in which it is abundant today. Possibly Eucryphia spread during and since the late Tertiary cooling and Quaternary glaciations, which seem to have caused the extinction of numerous species from Tasmania (Hill \& Macphail 1985). Leaves of the rainforest shrub Anopterus glandulosus appear to be very susceptible to rapid physical and biological breakdown. Aristotelia leaves seem to be affected similarly to those of Atherosperma. It is predicted that they have little potential for fossilisation. In accordance with the results of O'Keefe \& Lake (1987) the thick phyllodes of A. melanoxylon appear resistant to breakdown, and should thus fossilise readily. Macrofossils of Acacia are known only from Plio-Pleistocene and later sediments (Hill \& Macphail 1985) and pollen is first recorded in southeastern Australia in the Miocene (Martin 1978). Therefore, if Acacia occurred in the early Tertiary of Tasmania it must have been very remote from depositional sites.

The results of this report emphasise that in a study of a fossil flora the possibility of the existence of different suites of species away from water must be considered, since leaves of these plants are much less likely to reach a situation where they could become fossilised.

\section{ACKNOWLEDGEMENTS}

This study received funding from the Tasmanian Forestry Research Council in the form of a grant to the Tasmanian Inland Fisheries Commission. R.J.C. receives a Commonwealth Post-graduate Research Award. Laboratory facilities and transport were provided by the Inland Fisheries Commission. We are grateful to Michael Pemberton and Brett Mawbey for assistance in the field and to Bob Hill for constructive comments on the manuscript.

\section{REFERENCES}

BARLOW, B.A., 1981: The Australian flora: its origin and evolution. In George, A.S. (Ed.): FLORA OF AUSTRALIA. VOLUME I. INTRO. DUCTION. Australian Government Publishing Service, Canberra: 25-75.

BIRKS, H.J.B. \& BIRKS, H.H., 1980: QUATERNARY PALAEOBOTANY. Edwin Arnold, London.

BUNN, S., 1986: Origin and fate of organic matter in Australian upland streams. In De Deckker, P. \& Williams, W.D. (Eds): LIMNOLOGY IN AUSTRALIA. CSIRO, Melbourne. Dr W. Junk Publishers, Dordrecht: 277-292.

COLHOUN, E.A., 1980: Quaternary fluviatile deposits from the Pieman Dam site, western Tasmania. Proc. R. Soc. Lond. B 207: 355-384.

FERGUSON, D.K., 1985: The origin of leaf assemblages - new light on an old problem. Rev. Palaeobot. Palynol. 46: 117-188.

HLL, R.S., 1983: Nothofagus macrofossils from the Tertiary of Tasmania. Alcheringa 7: 169-183

HILL, R.S., 1984: Tertiary Nothofagus macrofossils from Cethana, Tasmania. Alcheringa 8: 81-86.

HILL, R.S. \& GIBSON, N., 1986a: Distribution of potential macrofossils in Lake Dobson, Tasmania. J. Ecol. 74: 373-384.

HILL, R.S. \& GIBSON, N., 1986b: Macrofossil evidence for the evolution of the alpine and sub-alpine vegetation of Tasmania. In Barlow B.A. (Ed.): FAUNA AND FLORA OF ALPINE AUSTRALASIA. CSIRO, Canberra: 205-217.

HILL, R.S. \& MACPHAIL, M.K., 1983: Reconstruction of the Oligocene vegetation at Pioneer, northeast Tasmania. Alcheringa 7: 281-299.

HILL, R.S. \& MACPHAIL, M.K., 1985: A fossil flora from rafted Plio-Pleistocene mudstones at Regatta Point, Tasmania. Aust. J. Bot. 33: $497-517$

HOWARD, T.M., 1973: Studies in the ecology of Nothofagus cunninghamii Oerst. II. Phenology. Aust. J. Bot. 21: 79-92.

JARMAN, S.J. \& BROWN, M.J., 1983: A definition of cool temperate rainforest in Tasmania. Search 14: $81-87$.

MARTIN, H.A., 1978: Evolution of the Australian flora and vegetation through the Tertiary: evidence from pollen. Alcheringa 2: 181-202

O'KEEFE, M.A. \& LAKE, P.S., 1987: The decomposition of pine, eucalypt and Acacia litter in a small upland Victorian stream. Bull. Aust. Soc. Limnol. 11: 15-32. 
RAVEN, P.H. \& AXELROD, D.I., 1972: Plate tectonics and Australasian palaeobiogeography. Science 176: $1379-1386$.

SINGH, G., KERSHAW, A.P. \& CLARK, R., 1981: Quaternary vegetation and fire history in Australia. In Gill, A.M., Groves, R.H. \& Noble, I.R. (Eds): FIRE AND THE AUSTRALIAN BIOTA. Australian Academy of Science, Canberra: 23-54.

TURNBULL, C.R.A. \& MADDEN, J.L., 1983: Relationship of litterfall to basal area and climatic variables in cool temperate forests of southern Tasmania. Aust. J. Ecol. 8: 425-431.
WINTERBOURN, M.J., 1985: Sampling stream invertebrates. In Pridmore, R.D. \& Cooper, A.B. (Eds): BIOLOGICAL MONITORING IN FRESHWATERS: PROCEEDINGS OF A SEMINAR. Water and Soil Miscellaneous Publication 83. Water and Soil Directorate, Ministry of Works and Development for the National Water and Soil Conservation Authority, Wellington, 1985: 241-258.

(accepted 26 November 1987) 